the year 814 ; it is Chortonicum, and occurs among a number of geographical names, several of which refer to Gaul, so that Chortonicum may very well have meant the country of the Pictones. At all events, the great German philologist, Pott, at once saw that it was to be explained by reference to the word Cruithne, 'a Pict,' with which it decidedly goes as distinguished from its Brythonic equivalent Prydyn (or the older Priten) with an initial $p$. The Celtican form originally meant was some such vocable as Qurtonico-n, with the $q u$ which was usual in Celtican and early Goidelic, where it formed, in fact, one of the most conspicuous distinctions between those languages and Brythonic or Gaulish, in which $q u$ had been changed into $p$.

My remarks have again run into tiresome details, but it is only by attending to such small points that one can hope to force language to yield us any information in the matter of ethnology. It may perhaps help in some measure if I sum up what $I$ have been trying to say, thus :

The first race we have found in possession of the British Isles consisted of a small, swarthy population of mound-dwellers, of an unwarlike disposition, much given to magic and wizardry, and perhaps of Lappish affinities ; its attributes have been exaggerated or otherwise distorted in the evolution of the Little People of our fairy tales.

The next race consisted of a taller, blonder people, with blue eyes, who tattooed themselves and fought battles. These tattooed or Pictish people made the Mound Folk their slaves, and in the long-run their language may be supposed to have been modified by habits of speech introduced by those slaves of theirs from their own idiom. The affinities of these Picts may be called Libyan and possibly Iberian.

Next came the Celts in two great waves of immigration, the first of which may have arrived as early as the seventh century before our era, and consisted of the real ancestors of some of our Goidels of the Milesian stock, and the linguistic ancestors of all the peoples who have spoken Goidelic. That language may be defined as Celtican, so modified by the idioms of the population which the earlier Celts found in possession, that its syntax is no longer Aryan.

Then, about the third century B.c., came from Belgica the linguistic ancestors of the peoples who have spoken Brythonic; but in the majority of cases connected with modern Brythonic they are to be regarded as Goidels who adopted Brythonic speech, and in so doing brought into that language their Goidelic idioms, with the result that the syntax of insular Brythonic is no less nonAryan than that of Goidelic, as may be readily seen by comparing the thoroughly Aryan structure of the few sentences of old Gaulish extant.

Those are the races which have been inferred in the course of these remarks, in which I have proceeded on the principle that each successive band of conquerors has its race, language, and institutions eventually more or less modified by contact with the race, language, and institutions of those whom it has conquered. That looks simple enough when stated so, but the result which we get proves complicate. In any case, I have endeavored in this address to substitute for the rabble of divinities and demons, of fairies and phantoms that disport themselves at large in Celtic legend, a possible series of peoples, to each of which should be ascribed its own proper attributes. But that will only be possible if we can enlist the kindly aid of the muse of archeology.

JoHN RHYs.

\section{CAMPHOR SECRETED BY AN ANIMAL (POLY- ZONIUM).}

IN the vicinity of Syracuse, New York, nine or ten years ago a distinct odor of camphor was noticed in connection with a 
small diplopod, Polyzonium rosalbum, * but as this occurred after several hours of miscellaneous collecting in which my hands had been in contact with many plants, as well as with"other myriapods and insects, the origin of the scent could not be indubitably established. The observation was subsequently repeated both in Central New York and on Long Island, but there has been no opportunity to follow the matter up until the present season. Learning that Polyzonium is abundant in the town of Farmington, Ontario County, New York, I asked my friend Mr. Edgar Brown to send a number of living specimens to me at Washington. These have recently arrived in good condition and have made a satisfactory exhibition of their camphor-producing powers. From a full-grown specimen taken between the thumb and finger no odor is usually perceptible at first, but as the animal struggles to escape, and especially if slight pressure be exerted, the characteristic smell of camphor becomes very distinctly appreciable. If a lens be used at the same time, a milky fluid is seen to exude from the dorsal pores, a pair of which is to be found on each segment behind the fourth. On exposure to the air the liquid very quickly takes on a sticky consistence and may be pulled out into threads half an inch long or more. In addition to the smell there is also the flavor and sharp burning taste of camphor, lasting for a minute or two. The odor is likewise not persistent, gradually decreasing and finally disappearing in a short time.

To eliminate any possibility of error regarding the odor or the material it represents, the animals were submitted to Dr. Oscar Loew who agrees to the diagnosis and informs me that no other substance is recorded as having an odor likely to be mistaken for that of camphor, $\dagger$ and that

* Octoglena bivirgata Wood is probably a synonym. $\dagger$ In this connection it may be noted that while the existence of camphor as an animal secretion is still quite unknown. This does not, of course, exclude the possibility that a new compound is involved, but, as Dr. Loew admits, a chemical analysis of this animal camphor would require many thousands of the myriapods, while the human nose furnishes, after all, one of the most delicate of chemical tests. For present purposes, then, we must admit camphor as an animal as well as a vegetable substance.

In the economy of the secreting animal, camphor is undoubtedly to be looked upon as a physiological substitute for the prussic or hydrocyanic acid employed in the myriapods of the order Merochæta (Polydesmus and its allies) as a means of defense. The liquid is secreted in special glands opening on the surface of the segments at the so-called repugnatorial pores. In these flattened, twenty-segmented forms, as in Polyzonium, the repugnatorial secretion seems merely to well up in the pores and spread itself or stand in globules on the surface, whence it evaporates into the air and serves its purpose merely through the strong pungent odor. But in the cylindrical or Iuliform types of Diplopoda, and particularly in the large tropical genera Spirobolus and Spirostreptus, the repugnatorial apparatus is much more highly developed, so that the animals are able to eject to a distance of several inches a spray of a substance having a very powerful, acrid odor quite differ. ent from that of prussic acid. This imcamphor has been known hitherto only as a vegetable product it is not confined to a single plant or natural order. The principal commercial supplies come from. Cinnamomum camphora of the family Lauraceæ, a near relative of the cinnamon, but the Borneo camphor is differently formed by a tree (Dryobalanops aromatica) of the family Dipterocarpaceæ, while still another source is said to be Blumea balsamifera, a Chinese composite herb. These substances as well as the artificial camphor produced from spirit of turpentine and hydrochloric acid, though not identical in composition nor in physical properties, are closely related by their chemical structure. 
pregnates the atmosphere and frequently causes a smarting sensation in the eyes and nose, even when the animals are held at ar'm's length. At close range the eyes would certainly be most painfully if not seriously affected, and such injury is probably the ground for the fear in which large diplopods are held by the natives of many tropical countries, although the creatures are otherwise quite harmless and may be handled with impunity. In Porto Rico, for instance, it is universally believed that the local Spirobolus has a deadly sting in its tail.

When the repugnatorial liquid comes in contact with the skin of the hands a yellowish-green stain results, which gradually deepens to a dull purple. In one instance after collecting a considerable number of large Spirostrepti at Conakry, Senegambia, my hands, although washed soon after, became very deeply colored and the skin peeled from the stained areas a few days afterward. As is well known to students of the group, the alcohol in which these large diplopods are collected takes on similar colors, yellowish green at first, changing to a very deep purplish red, and has a characteristic disagreeable odor different from that of the living animal, but still in some respects suggesting it. This odor Dr. Loew considered similar to that of pyridine, though the presence of that substance might possibly be due to a taint of ' denaturalized' German alcohol and would not explain the corrosive action of the fresh fluid upon the cells of the epidermis, which fact denotes a peculiarity of chemical action known in very few organic compounds, and possessed neither by prussic nor by formic acid, now recognized as the poison of the centipedes as of many other animals.

The volatile character of the fluid, or at least of its active constituents, is also as apparent in Spirostreptus and Spirobolus as in Polyzonium and Polydesmus. Until disturbed and roused to defensive efforts the creatures are nearly or quite odorless, and some will bear considerable handling before discharging their batteries. Indeed that operation can scarcely be supposed to give pleasure to the animal since its own fumes are soon fatal when it is confined with them in a bottle or small box. The same is also true of Polydesmus, the ability to secrete Prussic acid involving no immunity to that poison when the creature is obliged to breathe its own gaseous secretion in a closed space. The possibility that a certain amount of resistance to prussic acid may, however, be developed in other animals is suggested by reliable testimony to the effect that one of the monkeys native in Liberia is fond of the locally common species of Oxydesmus (flavomarginatus, medius and grayi). There was no opportunity for me to verify this information, but places where the leaves and vegetable debris had been upturned, declaredly by the monkey in searching for his prey, were pointed out to me in the forest, and the flesh of the animal is commonly believed to have the odor of Oxydesmus and to be bitter, poisonous and inedible because of this remarkable and unique food habit, on which point the observation and opinion of the natives might be expected to be conclusive, nothing being refused by them which could by any possibility be eaten.

Direct exposure to the light and heat of the sun is also speedily fatal to many Diplopoda. In the case of small and delicate species this might not seem suprising, but the very large and heavily armored Spiroboli and Spirosirepti are also unable to recover after full illumination for a short time. In ten or fifteen minutes they are often quite dead. That this susceptibility may prove to be the result of some chemical change or dissociation of the stored repugnatorial fluid is apparently indicated by the fact that 
animals killed by expósure to the sun do not stain the alcohol as described above, the repugnatorial fluid having oozed out and been evaporated from the surface of the segments. This suggests a further possibility that the material elaborated in the repugnatorial glands may not attain its final and effective composition until directly or indirectly acted upon by the air. Camphor would furnish a somewhat different and probably more difficult problem, for though not actively poisonous to us, its fumes seem to have a very detrimental effect upon many of the tracheate Arthropoda. That some of the predaceous insects might be active enemies of such an animal as Polyzonium is entirely possible, but it is also to be considered that the small as well as the large Diplopoda may owe to their repugnatorial secretions their comparative immunity from mites and other parasites which commonly attack animals of similar habits. The larger forms are not entirely immune from mites, but when these are found they seem always to be confined to the immediate neighborhood of the head, never occurring on the poriferous segments.

This susceptibility to injury from exposure to sunlight may prove to be an explanation of the hitherto not obvious utility of the eyes of the Diplopoda, which are more sensitive spots, probably quite incapable of effective vision, though possibly of service in seeking shelter. Perhaps some causal relation may also be found in the fact that in the large order Merocheta, where Prussic acid is secreted, eyes are entirely wanting, though absent only in a few subterranean species of other groups. This absence of eyes also renders apparently meaningless the fact recorded by Bruner and Kenyon,*

\footnotetext{
* Bruner, Insect Life, 1891, III., 319, describes a yellow spot near the lateral edge of each carinæ as luminous. Kenyon, Publications of the Nebraska Academy of Science, 1893, 16, doubts whether the luminosity belongs to the repugnatorial secretion be-
}

that the repugnatorial secretion of a $\mathrm{Ne}$ braska species is luminous. From the sexual standpoint the odor might have a function though the light were merely incidental, but when the nocturnal habits of the animals are considered, phosphorescence may be looked upon as affording a protection additional to that of the odor of the repugnatorial liquid.

In the preceding discussion there has been no intention to imply that the repugnatorial secretion of Spirobolus is the same as that of Spirostreptus, though there seems to be greater similarity than with Polydesmus. Moreover the milky and particularly malodorous liquid excreted by Spirostrephon lactarium and probably by other members of the family Lysiopetalidæ is also obviously different from any of the others, so that the elaboration by the class Diplopoda of at least four repugnatorial compounds seems certain, and the idea that Prussic acid is manufactured by all the pore-bearing Diplopoda is shown to be a quite unwarranted generalization.

Two other substances of similar quality and function may be of interest in this connection. One is to be found in the material forcibly ejected by the so-called ' nasuti' caste or soldiers of termites of the genus Ptyotermes. There are several such species in Liberia, the largest, $P$. liberiensis, being deeper brown than the others and having the soldiers of such size that the jets of liquid can by careful observation be seen by the naked eye. The fluid, which is secreted in a special cephalic gland, is clear and watery and does not stain the hands, though alcohol in which the insects are collected becomes dark brown. A smarting sensation in the eyes cause it is described as confined to stationary spots. But in a state of rest it could be expected that only small quantities of the repugnatorial fluid would be continuously given off, and evaporation would take place in the cavity of the pore. Kenyon calls the species Fontaria luminosa, but a study of his specimens shows that the generic affinity is rather remote. 
and nose is also distinctly appreciable. The odor is even more disagreeably pungent and penetrating than that of Spirostreptus and has an almost nauseating quality which pervades the nests and galleries of the species and can readily be detected in houses attacked by this termite. [Isonitriles?] Like the secretion of Polyzonium the liquid becomes sticky on exposure to the air, and the insect enemies upon which it is squirted have their antennæ stuck to their bodies and are otherwise disabled.

Another comparable secretion exists in the suborder Geophiloidea of the class Chilopoda which includes the centipedes and their allies, now no longer supposed to have more than the remotest affinity with the Diplopoda. The Geophiloidea are long, slender, carnivorous animals, having from 31 to 173 leg-bearing segments, the number being always uneven. They live in the ground or in the crevices of decaying wood, coming to the surface only at night. In nearly all the species the ventral plate of each segment is perforated by minute pores which are the openings of unicellular glands. In one species, Orphnceus phosphoreus, common in the tropics, the secretion which flows from these pores has attracted considerable attention because of its brilliant luminosity, the animal leaving behind it a trail of greenish light. Several other species of different families are known to give off light and that power is probably general in the suborder. Although supposed to be a sexual phenomenon, the purpose of this luminosity, as in the diplopod mentioned above, is scarcely thus explainable, since all the Geophiloidea are, like the Merocheta, quite eyeless. The parallel goes, moreover, a step farther, since the liquid which exudes from the ventral spores of the Geophiloidea*

\footnotetext{
* This observation was made and has been verified on two or three occasions with Geophilus rubens Say, of which $G$. cephalicus Wood is a synonyn. The species is common in northeastern Nonth America.
}

has also an odor closely similar if not identical with that of prussic acid, though like the repugnatorial fluid of Polyzonium and Ptyotermes it soon assumes an elastic consistence and may be drawn out in threads. Whether this material has anything to do with the webs which the Geophiloidea are said to spin is not known, but the general function is probably repugnatorial and in this the luminous quality might also be of use. The tendency of so many of these secretions to become fibrillar also suggests mention of the fact that in the diplopod suborder Chordeumatoidea, where repugnatorial pores are absent, silk-glands are present, though they can scarcely have any morphological relationship to the pores.

But leaving these unknown substances out of further account, the fact that camphor and prussic acid are quite unrelated chemically is a matter of interest from the evolutionary standpoint. No doubt has ever been expressed that the repugnatorial pores are exact homologues throughout the class Diplopoda, outside of which no morphological equivalents have been recognized. That organs of common origin should produce for the same purposes substances so utterly unlike is a fact that seems very difficult of explanation by existing theories, either from the biological or from the chemical standpoint. For the equipment of pores derived from a common ancestral type and having maintained their repugnatorial function, it would seem necessary to predicate a gradual change of secretion from camphor to prussic acid or from prussic acid to camphor, or from some intermediate substance to these two and to the other unknown derivatives. We have, in faet, a chemico-biological question which can be placed on a genuine phylogenetic basis, the problem being to construct a chain of evil smelling or at least aromatic substances to connect camphor with prussic 
acid and pyridine or whatever the unknown quantities may prove to be.

Returning to the camphor-producing animal, it may be noted that Polyzonium is a circumpolar genus and is represented in Europe by $P$. germanicum, with which our American form is closely related if not identical. That the nature of the secretion should have remained undiscovered is not suprising in view of the fact that the animal is small ( 15 by $2 \mathrm{~mm}$.) and of very retiring habits, affecting only the humus of moist, undisturbed forest regions. Moreover it has a very peculiar appearance and would generally be taken for a worm or a small slug rather than for a myriapod, and may not give off its repugnatorial secretion unless injured. Taxonomically it is looked upon as the type of a distinct family, Polyzonidæ, also of a suborder, Polyzonoidea, in which it is, however, associated with a tropical family, Siphonotidæ. With two other suborders also consisting of few genera and few and local species, but having a wide general distribution, the order Colobognatha is made up. This has been found to differ* from other diplopods, not only in the possession of many primitive characters, but in having the copulatory legs not truly homologous, a very reliable indication of long separation in evolutionary history. Of course this is no reason for supposing that Polyzonium has preserved the ancestral type of repugnatorial secretion, particularly in view of the fact that camphor is a much more complex substance than prussic acid. That the biological affinity is thus remote, may, however, encourage the chemists by providing all the time necessary for any succession of reactions they may see fit to predicate.

WAshingtoN, D. C.

O. F. Соок.

* "A new Character in the Colobognatha, with drawings of Siphonotus," Ameriean Naturalist, Oot. 1896, xxx, 839-844.

\section{PROGRESS IN METEOROLOGICAL KITE FLYING.}

The value of the kite in meteorological research is now universally recognized. As a result of improvements in apparatus and methods successively greater heights have been reached until within the past fifteen months, 4300 meters or higher has been reached by Teisserenc de Bort, in France, while at Blue Hill Observatory in this country, 4,850 meters was attained on July 19, 1900. This last height is greater than that of any American balloon ascension where accurate observations were made. Since meteorological kite flying may be said to have begun practically within the past seven years, it is improbable that the limits of maximum height or of efficient work have been reached; for as yet but few individuals or institutions have undertaken such work on an adequate scale.

The work at Blue Hill during the past year indicates that improvement may be expected (1) as a result of further modifying the kite and (2) from experiments to determine the size of wire best adapted for use as line.

The original Hargrave kite with flat lifting surfaces usually attained an angular altitude of $54^{\circ}$ to $56^{\circ}$ when flown from a short line. The addition of an intermediate lifting surface in the front cell possibly increased this average altitude to $58^{\circ}$ or $59^{\circ}$ but rendered the kite unstable. In winds of 15 meters per second, or higher, the flat surfaced kites are driven downward by the increase of pressure upon the front edges of the cells, high flights being possible only during favorable conditions. By the addition of rigid curved sustaining surfaces the altitude reached by the best kites is now about $66^{\circ}$, and the average of several kites is about $64^{\circ}$. The effect of wind pressure on the edges of the cells does not seriously affect the altitude until the velocity of the 